\title{
Mapping daily evapotranspiration and dryness index in the East African highlands using MODIS and SEVIRI data
}

\author{
Z. Sun ${ }^{1}$, M. Gebremichael ${ }^{1}$, J. Ardö ${ }^{2}$, and H. A. R. de Bruin ${ }^{3}$ \\ ${ }^{1}$ Civil \& Environmental Engineering, University of Connecticut, 261 Glenbrook Road, Storrs, CT 06269-2037, USA \\ ${ }^{2}$ Department of Earth and Ecosystem Sciences, Lund University, Lund, Sweden \\ ${ }^{3}$ Associated Professor Emeritus, Wageningen University, freelance researcher, Bilthoven, The Netherlands
}

Received: 10 August 2010 - Published in Hydrol. Earth Syst. Sci. Discuss.: 26 August 2010

Revised: 12 November 2010 - Accepted: 9 January 2011 - Published: 18 January 2011

\begin{abstract}
Routine information on regional evapotranspiration (ET) and dryness index is essential for agricultural water management, drought monitoring, and studies of water cycle and climate. However, this information is not currently available for the East Africa highlands. The main purpose of this study is to develop (1) a new methodology that produces spatially gridded daily ET estimates on a (near) real-time basis exclusively from satellite data, and (2) a new dryness index that depends only on satellite data and weather forecast data. The methodology that calculates daily actual ET involves combining data from two sensors (MODIS and SEVIRI) onboard two kinds of platforms (Terra - polar orbit satellite and MSG - geostationary orbit satellite). The methodology is applied to the East African highlands, and results are compared to eddy covariance measurements at one site. Results show that the methodology produces ET estimates that accurately reproduce the daily fluctuation in ET but tends to underestimate ET on the average. It is concluded that the synergistic use of the polar-orbiting MODIS data and the geostationaryorbiting SEVIRI data has potential to produce reliable daily ET, but further research is needed to improve the accuracy of the results. This study also proposes an operational new dryness index that can be calculated from the satellite-based daily actual ET estimates and daily reference ET estimates based on SEVIRI data and weather forecast air temperature. Comparison of this index against ground measurements of daily actual ET at one site indicates that the new dryness index can be used for drought monitoring.
\end{abstract}

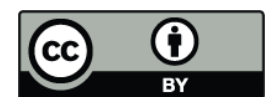

Correspondence to: M. Gebremichael (mekonnen@engr.uconn.edu)

\section{Introduction}

Routine information on regional evapotranspiration (ET) and dryness index is essential for agricultural water management, drought monitoring, and studies of water cycle and climate dynamics (Potter et al., 1993; Churkina et al., 1999; Nemani et al., 2002). The MODerate resolution Imaging Spectroradiometer (MODIS) sensor on board Terra and Aqua satellites has long been recognized for its potential to produce frequent ET maps across the globe. Few researchers have used MODIS data to produce ET maps in different regions for some periods (Nagler et al., 2005; Patel et al., 2006; Cleugh et al., 2007; Mallick et al., 2007; Mu et al., 2007; Wang et al., 2007; Leuning et al., 2008; Venturim et al., 2008). However, despite these limited successes, we still do not have operational daily ET maps across Africa. This is because current MODIS-based ET algorithms represent only "instantaneous or snapshot" values (while daily aggregated ET maps are more meaningful and useful), and methods of scaling up the instantaneous value to daily require ground-based measurements of radiation, which are not readily available in the East African highlands. The first objective of this study is to develop a methodology for estimating daily ET exclusively from satellite data through the use of a combination of geostationary and polar orbiting satellite data.

Dryness indices of land surface provide useful information for agricultural and water resources managements. Among various dryness indices, two meteorological dryness indices are widely accepted and used, the Palmer's Drought Severity Index (PSDI) (Palmer, 1965; Guttman et al., 1992) and the Standardized Precipitation Index (SPI) (Tsakiris and Vangelis, 2004). The PDSI is a "meteorological" drought index that responds to weather conditions that have been abnormally dry or abnormally wet. The PDSI is calculated based

Published by Copernicus Publications on behalf of the European Geosciences Union. 
on precipitation, temperature and available water content of the soil. The major problem with the PDSI index is that only point measurements with over 15-20 years of record can be used in the calculation of the index and that the spatial coverage of the point meteorological measurement in the East African highlands is scarce. The SPI is another meteorological index that suffers from the same problems as the PSDI index except that it overcomes the time lag problem associated with the PSDI index.

In addition, the major pitfall of both indices is that they contain no economic component which is important to declare drought and seek help from the Government and donors. Yield is linearly related to accumulative evapotranspiration through the evapotranspiration production functions (Doorenbos and Kassam, 1979). Therefore, evapotranspiration-based indices of drought or dryness are much more useful for real-world applications. Doorenbos and Pruitt (1977) developed the water requirement satisfaction index (WRSI), and Jackson et al. (1981) developed the Crop Water Stress Index (CWSI). Both of them are determined by actual and potential ETs that require intensive ground-based measurements. The second objective of this study is to develop a dryness index that is based on satellite data and weather forecast data. In this study, we develop and apply a new methodology to calculate daily ET and dryness index over the East African highlands, and assess the accuracy of the results by comparing them against flux tower measurements at one site in Sudan.

\section{Data}

The proposed methodology (in Sect. 3) requires inputs of MODIS and geostationary-orbiting satellite data to calculate daily actual ET. In addition to these inputs, weather forecast air temperature data are also required to calculate the dryness index. The results of this methodology are validated using ground measurements from an eddy covariance (EC) flux site. Below, we describe these data sources.

MODIS Data - MODIS sensor onboard the Terra and Aqua polar-orbiting satellites has 36 spectral bands over a wide range at moderate resolutions $(250,500$, and $1000 \mathrm{~m})$ with almost daily coverage of the Earth (http://modis. gsfc.nasa.gov/). We used three MODIS/Terra land data products: 8-day land surface temperature, yearly International Geosphere-Biosphere Programme (IGBP) land cover map, and 16-day Normalized Difference Vegetation Index (NDVI).

SEVIRI Data - the Spinning Enhanced Visible InfraRed Imager (SEVIRI) sensor onboard the Meteorological Second Generation (MSG) geostationary-orbiting satellite provides 30/15-min observations of land surface and the atmosphere in 12 spectral bands for Europe, South America, and Africa at $3.1 \mathrm{~km}$ spatial resolution at nadir (http://www.esa.int/ SPECIALS/MSG/). We used five SEVIRI/MSG data prod- ucts: 30-min downwelling shortwave radiation flux (DSSF), 30-min downwelling long-wave radiation flux (DSLF), 15min land surface temperature (LST), daily vegetation cover fraction (FVC), and static auxiliary digital elevation (DEM, see Fig. 1) data.

Weather forecast air temperature data - we obtained air temperature at $2 \mathrm{~m}$ height $\left(T_{2} \mathrm{~m}\right)$ from forecasts provided by the European Centre for Medium-range Weather Forecasts (ECMWF) model. The initial 3-hourly $T_{2 \mathrm{~m}}$ forecasts at a resolution of about $25 \mathrm{~km}$ are linearly interpolated in time to hourly, and bi-linearly interpolated in space to the SEVIRI/MSG resolution. The $T_{2 \mathrm{~m}}$ values undergo a further adjustment to correct differences between the ECMWF mode surface topography and SEVIRI pixel altitude using a constant lapse rate of $0.67^{\circ} \mathrm{C} / 100 \mathrm{~m}$. See Trigo et al. (2011) for details about ECMWF data.

Ground measurements - flux sites are sparse in Africa, especially in the East African highlands. Among the CarboAfrica flux network, we only found the SD-Dem flux site in the East African highlands. So our site selection was dictated by data availability. We obtained ground measurements of quality-controlled 30-min net radiation, soil heat flux, sensible and latent heat fluxes from the SD-Dem CarboAfrica flux tower site in Sudan (see Fig. 1 for the location map). The SD-Dem site is located at $13.2829^{\circ} \mathrm{N}$, $30.4783^{\circ} \mathrm{E}, 540 \mathrm{~m}$ above sea level, and is characterized by sparse acacia savanna, mean annual air temperature of $28^{\circ} \mathrm{C}$, and mean annual precipitation of about $320 \mathrm{~mm}$ with the majority falling during June to October (Ardö et al., 2008; Sjöström et al., 2009). A LI7500 (Li-Cor, Lincoln, US) open-path infrared $\mathrm{CO}_{2}$ and $\mathrm{H}_{2} \mathrm{O}$ gas analyzer and a GILL R3 Ultrasonic Anemometer (GILL Instruments, UK) were mounted $9 \mathrm{~m}$ above the ground, approximately $4 \mathrm{~m}$ above the sparse canopy. About $400 \mathrm{~m}$ away from the flux tower was a micrometeorological station that measures routine meteorological data such as net radiation, soil heat flux, air temperature, humidity and wind speed. We collected ground measurements during the period 1 July-29 December 2007.

\section{Methodology}

The proposed methodology for the estimation of daily actual ET and dryness index is illustrated with a flow chart in Fig. 2. Here, we discuss in detail the algorithms involved.

\subsection{Daily actual ET $\left(\mathbf{E T}_{\mathbf{d}}\right)$}

$\mathrm{ET}_{\mathrm{d}}(\mathrm{mm} /$ day) is estimated using inputs of daily net radiation $\left(\mathrm{Rn}_{\mathrm{d}}\right)$ and daily soil heat flux $\left(G_{\mathrm{d}}\right)$ derived from SEVIRI and "instantaneous" evaporative fraction (EF) during the daytime derived from MODIS, and making the commonly used assumption that the EF is constant during the daytime (e.g., Brutsaert and Sugita, 1992): 


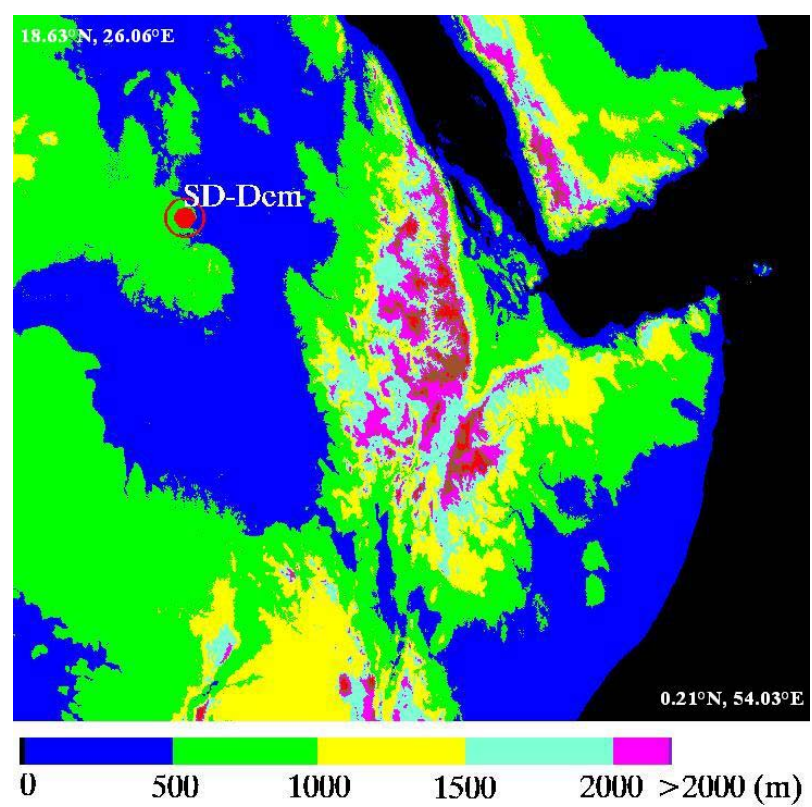

Fig. 1. Elevation of the study region, and location of the SD-Dem validation site in Sudan.

$$
\begin{aligned}
\mathrm{ET}_{\mathrm{d}} & =\mathrm{EF}_{\mathrm{d}} \times\left(\mathrm{Rn}_{\mathrm{d}}-G_{\mathrm{d}}\right)=\frac{30 \times 60}{\lambda} \mathrm{EF}_{\text {MODIS }} \\
& \times \sum\left(\mathrm{Rn}_{\text {SEVIRI }}-G_{\text {SEVIRI }}\right)
\end{aligned}
$$

where $\lambda$ is the latent heat of vaporization, the subscript SEVIRI indicates that the data comes from the 30-min SEVIRI product, the subscript MODIS indicates that the data comes from the MODIS product which is typically available as "instantaneous" 8-day composite product, and the summation sign represents the summation of the 30-min data during a given day. Each of the terms involved in Eq. (1) are described below.

$\mathrm{EF}_{\text {MODIS }}$ is derived exclusively from MODIS data using the following equation:

$\mathrm{EF}_{\text {MODIS }}=\frac{\mathrm{ET}_{\text {MODIS }}}{Q_{\text {MODIS }}}$

where $Q(=\mathrm{Rn}-G)$ is the available energy. We obtained $\mathrm{ET}_{\text {MODIS }}$ and $Q_{\text {MODIS }}$ in $\mathrm{W} / \mathrm{m}^{2}$ using our recently developed algorithm known as Sim-ReSET. Based on the energy balance of land surfaces, the Sim-ReSET model avoids the calculation of aerodynamic resistance by using a reference dry bare soil and the assumption that wind speed at the upper boundary of the atmospheric surface layer is laterally homogenous, but the model still considers the aerodynamic characteristics of land using canopy height. All inputs can be readily obtained from satellite remote sensing, which allows mapping regular real-time ET rates (Sun et al., 2009). In this study, three MODIS products are required as input: land surface temperature, NDVI and land cover type.

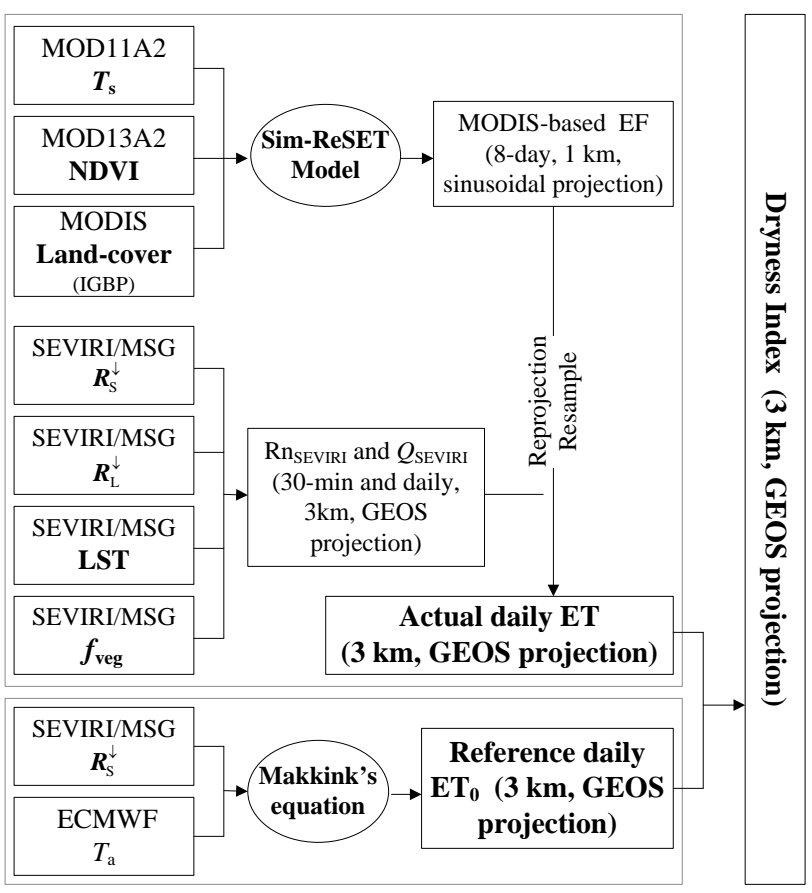

Fig. 2. Flowchart of the proposed methodology to estimate daily actual ET, daily reference ET, and daily dryness index.

$\mathrm{Rn}_{\text {SEVIRI }}$ is derived exclusively from SEVIRI data using the following equation:

$$
\begin{aligned}
& \mathrm{Rn}_{\mathrm{SEVIRI}}=\left(1-\alpha_{\mathrm{SEVIRI}}\right) R_{\mathrm{S}-\mathrm{SEVIRI}}^{\downarrow}+R_{\mathrm{L}-\mathrm{SEVIRI}}^{\downarrow} \\
& \quad-\varepsilon_{\text {SEVIRI }} \sigma T_{\mathrm{S}-\mathrm{SEVIRI}}^{4}
\end{aligned}
$$

where $\alpha$ is albedo, $\varepsilon$ is emissivity, $R_{\mathrm{S}}^{\downarrow}$ is downwelling shortwave radiation, $R_{\mathrm{L}}^{\downarrow}$ is downwelling long-wave radiation, and $T_{\mathrm{S}}$ is surface temperature. $R_{\mathrm{S}}^{\downarrow}, R_{\mathrm{L}}^{\downarrow}$, and $T_{\mathrm{S}}$ are directly from SEVIRI product. Both $\alpha$ and $\varepsilon$ are estimated by means of SEVIRI FVC data (Sun et al., 2009).

$G_{\text {SEVIRI }}$ is also derived exclusively from SEVIRI using the following equation:

$$
\begin{aligned}
& G_{\text {SEVIRI }}=\operatorname{Rn}_{\text {SEVIRI }}\left[f_{\text {veg-SEVIRI }} \Gamma_{\text {veg }}\right. \\
& \left.\quad+\left(1-f_{\text {veg-SEVIRI }}\right) \Gamma_{\text {soil }}\right]
\end{aligned}
$$

where $f_{\text {veg }}$ is the fractional vegetation cover (FVC), $\Gamma_{\text {veg }}$ and $\Gamma_{\text {soil }}$ are the ratios of soil heat flux to net radiation for vegetation and bare soil. Both of them can be approximately considered as constants, 0.1 and 0.4 , respectively (Sun et al., 2009).

Matching MODIS and SEVIRI pixels - MODIS data are available at $1 \mathrm{~km}$ spatial resolution in sinusoidal projection while SEVIRI data are available at $3.1 \mathrm{~km}$ spatial resolution at nadir in geostationary satellite view (GEOS) projection. We reprojected and resampled MODIS data to match the SEVIRI data. 


\subsection{Dryness Index (DI)}

Similar to the CWSI (Jackson et al., 1981) and the WRSI (Doorenbos and Pruitt, 1977), Anderson et al. (2007) proposed the evaporative stress index (ESI) which is determined from actual and potential ET. The potential ET is typically calculated by multiplying the reference evapotranspiration $\left(\mathrm{ET}_{0}\right)$ by the crop coefficient $\left(K_{\mathrm{c}}\right)$ (Allen et al., 1998). The reference ET is standardized to ideal grass, a hypothetical surface of 8 to $15 \mathrm{~cm}$ tall green grass cover of uniform height, actively growing, completely shading the ground and not short of water (de Bruin and Lablans, 1998). It is difficult to estimate $K_{\mathrm{c}}$ from SEVIRI data due to the crop type heterogeneity in the large SEVIRI pixel. We propose a new dryness index (DI) that avoids $K_{\mathrm{c}}$ as follows:

$\mathrm{DI}=\left\{\begin{array}{l}1-\frac{\mathrm{ET}_{\mathrm{d}}}{\mathrm{ET}_{0}}, \text { for } \mathrm{ET}_{0} \geq \mathrm{ET}_{\mathrm{d}} \\ 0, \text { for } \mathrm{ET}_{0}<\mathrm{ET}_{\mathrm{d}}\end{array}\right.$

We estimated $\mathrm{ET}_{0}$ using the modified Makkink equation. The modified Makkink equation is a suitable alternative for Penman's equation for the determination of $\mathrm{ET}_{0}$ (de Bruin and Lablans, 1998) as follows:

$\mathrm{ET}_{0}=c \frac{1}{\lambda} \frac{\Delta}{\Delta+\gamma} \sum R_{\mathrm{S}-\mathrm{SEVIRI}}^{\downarrow}$

where $c$ is a constant ( 0.65 suggested by de Bruin and Lablans, 1998), $\gamma$ is the psychrometric constant $\left(\mathrm{kPa} /{ }^{\circ} \mathrm{C}\right)$, and $\Delta$ is the slope of the saturation vapor pressure curve at air temperature $\left(\mathrm{kPa} /{ }^{\circ} \mathrm{C}\right)$. We obtained $T_{2 \mathrm{~m}}$ from forecasts provided by the ECMWF model. Then $\Delta$ is determined by means of $T_{2 \mathrm{~m}}$, and $\gamma$ is determined by means of the DEM data:

$$
\begin{aligned}
& \Delta=\frac{4098\left[0.6108 \exp \left(\frac{17.27 T_{2 \mathrm{~m}}}{237.3+T_{2 \mathrm{~m}}}\right)\right]}{\left(237.3+T_{2 \mathrm{~m}}\right)^{2}} \\
& P_{\mathrm{a}}=101.3\left(1-0.0065 \frac{z}{293}\right)^{5.26} \\
& \gamma=0.665 \times 10^{-3} P_{\mathrm{a}}
\end{aligned}
$$

where $P_{\mathrm{a}}$ is the atmospheric pressure $(\mathrm{kPa}), z$ is the elevation above sea level $(\mathrm{m})$. A detailed description of the $\mathrm{ET}_{0}$ algorithm is available in de Bruin et al. (2010).

\section{Results}

We applied our methodology to obtain satellite-based estimates of dryness index and daily actual and reference ETs for the Northeast Africa for the year 2007. Figure 3 shows sample maps for different seasons. Since $\mathrm{ET}_{0}$ is controlled by solar radiation, air temperature, and air pressure, its values are comparatively low in mountainous regions with high altitudes (shown in brown and blue colors in Fig. 3). During the rainy season in Ethiopia, daily actual ET values are high

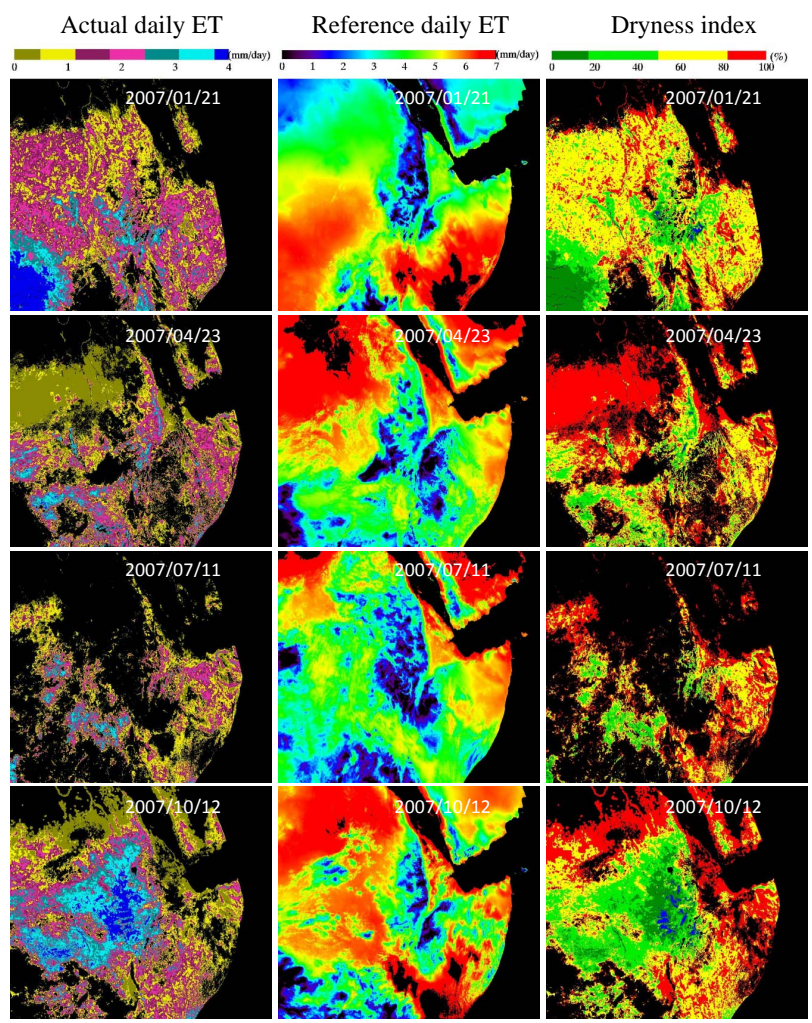

Fig. 3. Sample maps of (left panel) actual daily ET, (middle panel) daily reference ET, and (right panel) daily dryness index in different seasons in the study region.

(shown in blue) and dryness index values are low (shown in green), as expected. Figure 4 shows time series of estimated actual daily ET, estimated reference daily ET, EC-based observed ET, and estimated dryness index at the SD-Dem site in 2007. Due to missing data, some data lines are discontinuous.

The accuracy of our results was assessed through comparison with ground-based measurements. In Fig. 5, the satellitebased daily actual ET estimates are compared with groundbased measurements at the SD-Dem site in Sudan. There is a good correlation $\left(R^{2}=0.73\right)$ between our satellite-based estimates and ground measurements, however, the satellite estimates tend to underestimate the daily actual ET by about $18 \%$. The mean absolute error (MAE) is $0.92 \mathrm{~mm} /$ day, which is better than the $1 \sim 1.5 \mathrm{~mm} /$ day range reported in other validation studies of satellite ET estimation (e.g., Carlson et al., 1995; Gómez et al., 2005; Sánchez et al., 2008). In Fig. 6, the daily satellite-based dryness index estimates are compared against ground-based daily actual ET measurements at the SD-Dem site. There is a good correlation $\left(R^{2}=0.72\right)$ between the two, indicating that the satellite-based dryness index estimates are reasonable. Ideally, the dryness index should be 1.00 when daily actual ET is 0 , and should decrease with increasing ET. Our results are consistent with this 


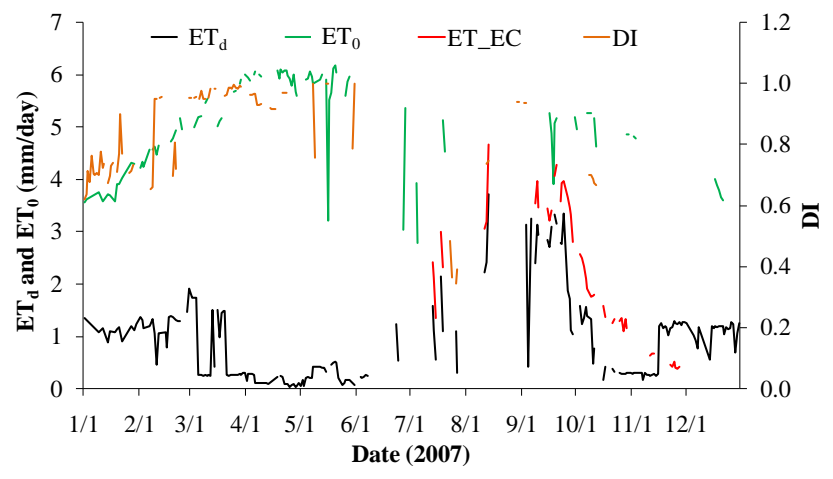

Fig. 4. Time series of estimated actual daily ET $\left(\mathrm{ET}_{\mathrm{d}}\right)$, estimated reference daily ET $\left(\mathrm{ET}_{0}\right)$, eddy covariance-based observed ET (ET_EC), and estimated dryness index (DI) at the SD-Dem site in 2007.

expectation: the dryness index estimate is 1.04 when ET is 0 , and decreases with increasing ET with a good correlation $\left(R^{2}=0.72\right)$, indicating that the satellite-based dryness index estimates are reasonable. Validation of the satellite-based daily reference ET estimates in the Ethiopian highlands is addressed by de Bruin et al. (2010) who reported satisfactory results on the accuracy of the satellite-based estimates.

\section{Discussion}

Our results reveal that the synergistic use of MODIS and SEVIRI data has the potential to provide realistic values of daily actual ET, daily reference ET, and daily dryness index. However, the resulting daily ET values, calculated using our algorithm, tend to be underestimated as compared to the EC measurements at the SD-Dem site. The discrepancy between the two values could be caused by factors, such as algorithm limitation and the mismatch between the SEVIRI pixel and flux tower footprint, among others. In the following, we discuss these issues in further detail.

Error in net radiation - the daily net radiation is estimated by summing up the 30-min net radiation obtained from the SEVIRI data during the day. In cloudy sky conditions, the remotely sensed radiation and surface temperature data are not available, and this leads to underestimation of the daily net radiation on cloudy days. Figure 7 indicates that cloudy or partially cloudy days usually occur in wet seasons. Validation results reported by LSA-SAF (2008) indicate that the SEVIRI LST values tend to overestimate surface temperature, and this leads to underestimation of the daily net radiation. LSA-SAF (2009) also reported underestimation of the SEVIRI downwelling shortwave radiation, which again leads to underestimation of the daily net radiation. Our comparison result shows that daily net radiation estimates from the SEVIRI data are underestimated with a MAE of $1.46 \mathrm{~mm} /$ day (equivalent evaporation in $\mathrm{mm} /$ day) (Fig. 8). Underestima-

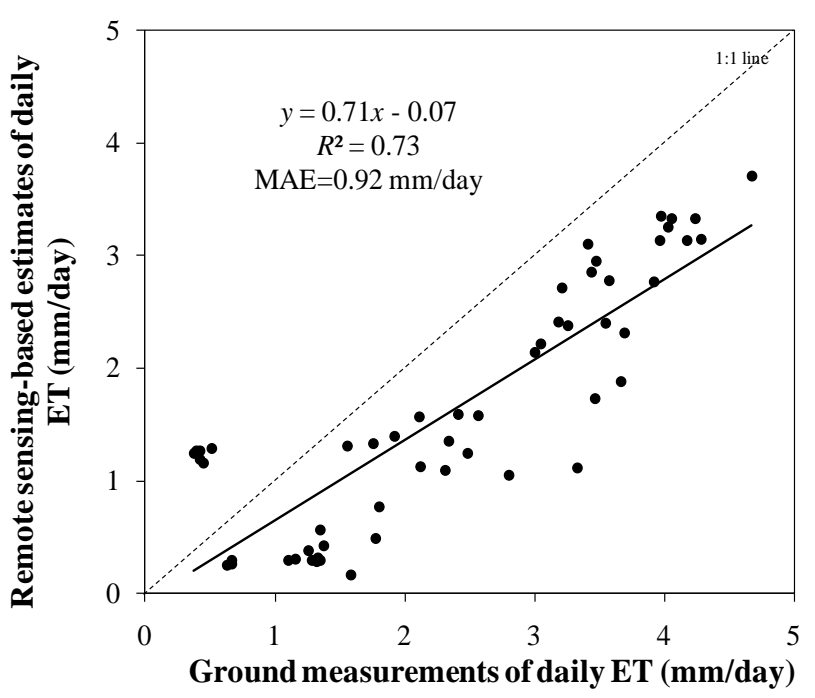

Fig. 5. Comparison of satellite-based daily actual ET estimates and eddy covariance measurements of daily actual ET at the SD-Dem site.

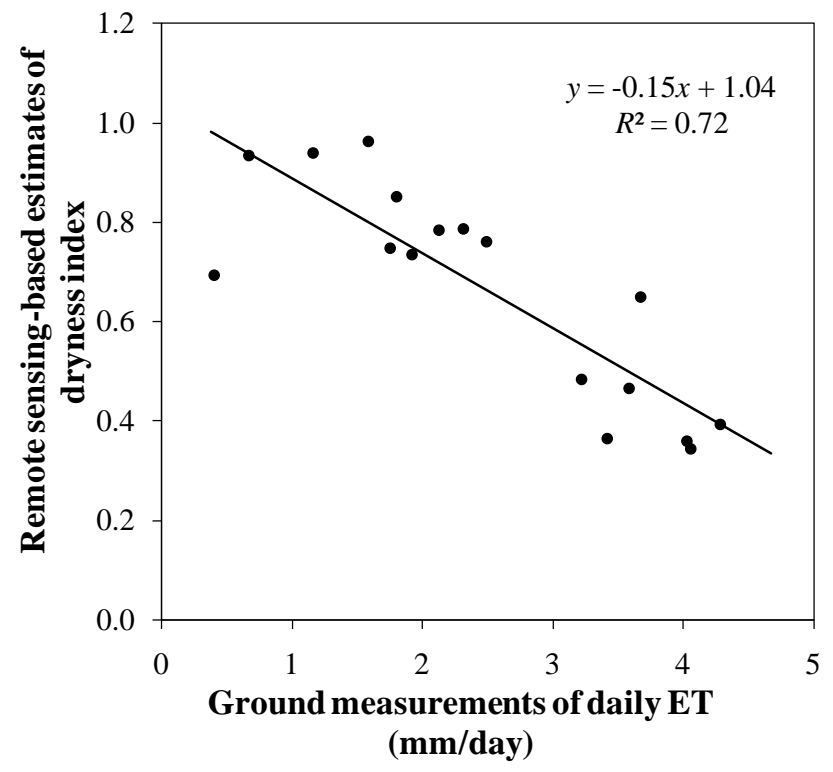

Fig. 6. Satellite-based daily dryness index estimates versus eddy covariance measurements of daily actual ET at the SD-Dem site.

tion of daily net radiation directly leads to underestimation of actual daily ET, and this is consistent with our finding that our algorithm tends to underestimate the daily actual ET.

Errors and assumption in Evaporative Fraction - EF is estimated by means of the VI-Ts diagram in the Sim-ReSET model (Sun et al., 2009). It is difficult to establish a correct VI-Ts diagram in dry seasons or regions due to the lack of pixels with full ranges of VI and surface moisture (Sun et al., 2008). As shown in Fig. 9, EF values estimated from 


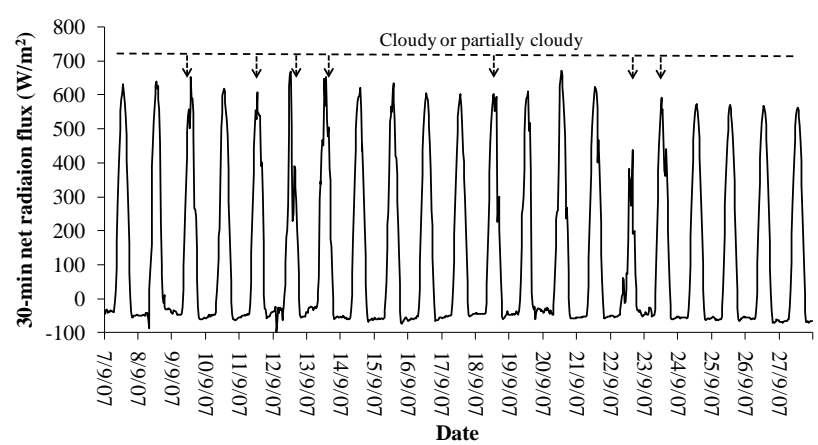

Fig. 7. Samples of daily patterns of 30-min net radiation during the period 7-27 September 2007 at the SD-Dem site.

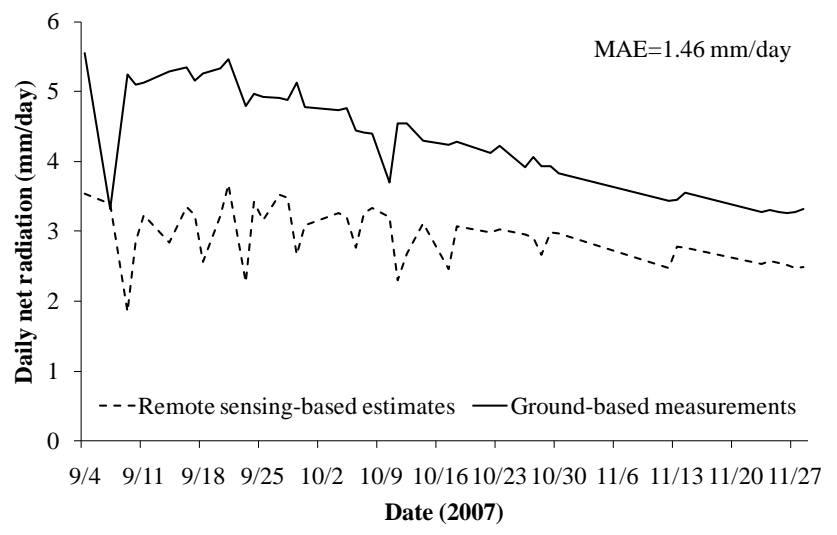

Fig. 8. Daily net radiation time series of remote sensing-based estimates and ground-based measurements at the SD-Dem site in 2007.

MODIS data are consistent with EF values calculated from EC flux data in wet seasons from June to October, but a significant difference is found in dry seasons in November at the SD-Dem site. Misclassifying a moderately dry pixel as a wet pixel results in overestimating EF, and thus overestimating ET. The assumption of constant daily EF was also tested at the SD-Dem site. The Terra satellite observes the Earth around 11:00 a.m. (10:30 a.m.-11:30 a.m.). The mean of EF from EC flux measurements at 10:30 a.m., 11:00 a.m., and 11:30 a.m. are generated to compare with the daily mean (09:00 a.m.-15:00 p.m.) of EC-based EF at the SD-Dem site. It is found that EF is relatively stable between 09:00 a.m. to 15:00 p.m. in the four seasons, but EF before 09:00 a.m. and after 15:00 p.m. tends to sharply increase. It is also found that the accumulated ET values during the period between 09:00 a.m. and 15:00 p.m. account for about $80 \%$ of corresponding daily ET values. Therefore, the mean of EF between 09:00 a.m. to 15:00 p.m. can fairly represent the daily EF value for daily ET calculations. The comparison results show that the mean of EF from EC flux measurements at 10:30 a.m., 11:00 a.m., and 11:30 a.m. agrees well with the daily mean (09:00 a.m.-15:00 p.m.) of EC-based EF at the

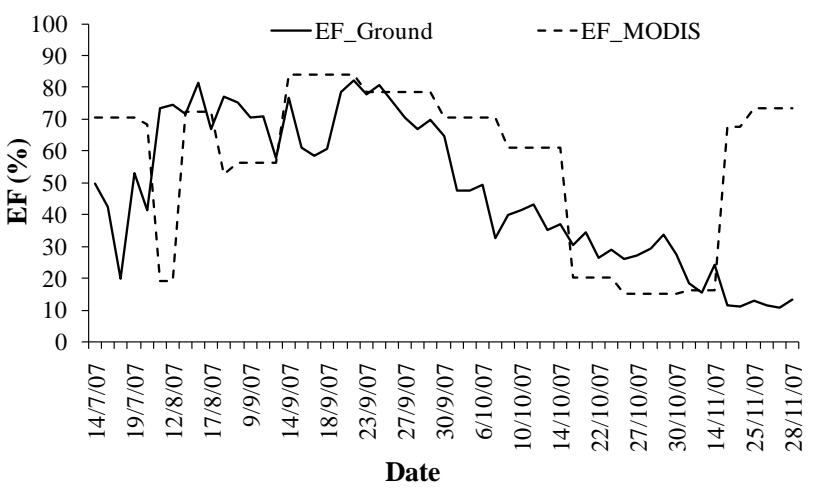

Fig. 9. Time series of EF estimated from MODIS data and calculated from eddy covariance flux data at the SD-Dem site in 2007.

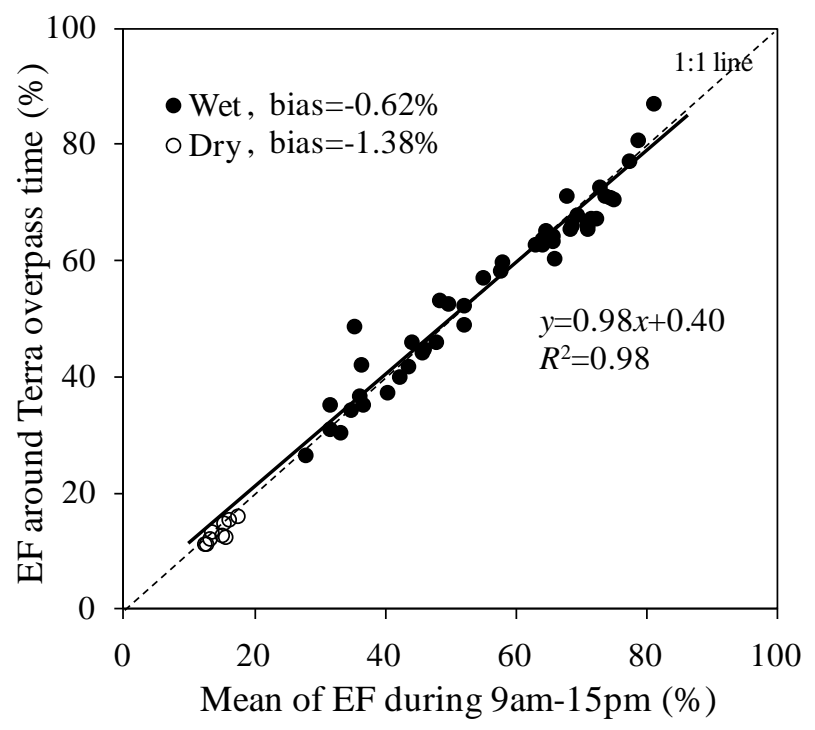

Fig. 10. Comparison of EF values around the Terra satellite overpass time and means of EF during 09:00 a.m.-15:00 p.m. based on ground EC measurements at the SD-Dem site.

SD-Dem site (Fig. 10). The slope, intercept, and $R^{2}$ of linear regression analysis are $0.98,0.40$, and 0.98 , respectively. The biases are $-0.62 \%$ and $-1.38 \%$ for wet and dry seasons, respectively. This indicates that EF values at the Terra satellite overpass time can represent the daily EF for estimating daily ET.

Mismatch between satellite and flux tower footprints there is a large discrepancy between the satellite-based ET resolution (3.1 km at nadir) and the footprint of flux tower (ten or hundred meters). In addition, flux towers are often set up close to vegetation areas, thus they tend to give higher ET measurements than spatially averaged values. 


\section{Conclusions}

We proposed a methodology to estimate actual ET, reference ET and dryness index on a daily time scale. The method combines information from the once-daily polarorbiting satellite data of MODIS/Terra and the 15/30-min geostationary-orbiting satellite data of SEVIRI/MSG. Daily actual ET is estimated from "instantaneous" EF (MODISbased), and daily net radiation and soil heat flux (SEVIRIbased). Daily reference ET is estimated from downwelling shortwave radiation (SEVIRI-based) and air temperature (ECMWF weather forecast product). We also proposed a new measure of drought, the dryness index which is calculated from the ratio between daily actual and reference ET.

We applied the methodology over the East African highlands, and calculated the daily actual ET, daily reference ET and dryness index for the year 2007. We compared the results against eddy covariance measurements of ET at the SDDem flux tower site in Sudan. Results show that there is a good agreement $\left(R^{2}=0.73\right.$ and $\mathrm{MAE}=0.92 \mathrm{~mm} /$ day $)$ between our satellite-based daily ET values and the eddy covariance measurements, however, our estimates tend to underestimate the daily actual ET values by about $18 \%$.

Based on the findings of this study, we conclude that the synergistic use of the polar-orbiting MODIS data and the geostationary-orbiting SEVIRI data has potential to produce reliable daily ET (actual or reference) and a measure of drought exclusively from satellite data and weather forecast data. We have presented a methodology of combining these datasets that adequately reproduces the daily temporal fluctuation of ET, but tends to underestimate actual daily ET. Further research is needed to improve the accuracy of the methodology, especially in cloudy sky conditions.

Acknowledgements. This study is funded by the NASA NIP Grant NNX08AR31G. The authors would like to thank Isabel Trigo of the LANDSAF team for providing gridded data for mapping reference ET, and also thank LP DAAC for providing MODIS data. The measurements at the SD-Dem were supported by EU through the CARBOAFRICA project and by the Swedish Research Council (contract 2004-3888).

Edited by: S. Uhlenbrook

\section{References}

Anderson, M. C., Norman, J. M., Mecikalski, J. R., Otkin, J. A., and Kustas, W. P.: A climatological study of evapotranspiration and moisture stress across the continental United States based on thermal remote sensing: 2. Surface moisture climatology, J. Geophys. Res.-Atmos., 112(D11), D11112, doi:10.1029/2006JD007507, 2007.

Allen, R. G., Pereira, L. S., Raes, D., and Smith, M.: Crop Evapotranspiration-Guidelines for Computing Crop Water Requirements, FAO Irrigation and drainage paper 56, Rome, Italy:
Food and Agriculture Organization of the United Nations, ISBN 92-5-104219-5, 1998.

Ardö, J., Mölder, M., El-Tahir, B. A., and Elkhidir, H. A. M.: Seasonal variation of carbon fluxes in a sparse savanna in semi arid Sudan, Carbon Balance Manage., 1, 3-7, doi:10.1186/17500680-3-7, 2008.

Brutsaert, W. and Sugita, M.: Application of self-preservation in the diurnal evolution of the surface energy budget to determine daily evaporation, J. Geophys. Res., 97(D17) 18, 377-382, 1992.

Carlson, T., Capehart, W., and Gillies, R.: A new look at the simplified method for remote-sensing of daily evapotranspiration, Remote Sens. Environ., 54, 161-167, 1995.

Churkina, G., Running, S. W., Schloss, A. L., and The Participants of the Potsdam NPP Model Intercomparison: Comparing global models of terrestrial net primary productivity (NPP): The importance of water availability, Glob. Change Biol., 5(suppl.1), 46$55,1999$.

Cleugh, H. A., Leuning, R., Mu, Q., and Running, S. W.: Regional evaporation estimates from flux tow and MODIS satellite data, Remote Sens. Environ., 106, 285-304, 2007.

de Bruin, H. A. R. and Lablans, W. N.: Reference crop evapotranspiration determined with a modified Makkink equation, Hydrol. Process., 12, 1053-1062, 1998.

de Bruin, H. A. R., Trigo, I. F., Jitan, M. A., Temesgen Enku, N., van der Tol, C., and Gieske, A. S. M.: Reference crop evapotranspiration derived from geo-stationary satellite imagery: a case study for the Fogera flood plain, NW-Ethiopia and the Jordan Valley, Jordan, Hydrol. Earth Syst. Sci., 14, 2219-2228, doi:10.5194/hess-14-2219-2010, 2010.

Doorenbos, J. and Kassam, A. H.: Yield response to water, Irrigation and Drainage Paper 33, FAO, United Nations, Rome, 1979.

Doorenbos, J. and Pruitt, W. O.: Crop water requirements, Irrigation and Drainage Paper 24, FAO, United Nations, Rome, 1977.

Gómez, M., Olioso, A., Sobrino, J. A., and Jacob, F.: Retrieval of evapotranspiration over the Alpilles/ReSeDA experimental site using airborne POLDER sensor and a thermal camera, Remote Sens. Environ., 96, 399-408, 2005.

Guttman, N., Wallis, J., and Hosking, J.: Spatial comparability of the Palmer Drought Severity Index, Water Resour. Bull., 28(6), 1111-1119, 1992.

Jackson, R. D., Idso, S. B., Reginato, R. J., and Pinter Jr., P. J.: Canopy temperature as a crop water stress indicator, Water Resour. Res., 17, 1133-1138, 1981.

Leuning, R., Zhang, Y. Q., Rajaud, A., Cleugh, H., and Tu, K.: A simple surface conductance model to estimate regional evaporation using MODIS leaf area index and the PenmanMonteith equation, Water Resour. Res., 44(10), W10419, doi:10.1029/2007WR006562, 2008.

LSA-SAF: Validation Report: Land Surface Temperature (LST), available at: http://landsaf.meteo.pt/, 2008.

LSA-SAF: Validation Report: Down-welling long wave flux (DSLF), available at: http://landsaf.meteo.pt/, 2009.

Mallick, K., Bhattacharya, B. K., Chaurasia, S., Dutta, S., Nigam, R., Mukherjee, J., Banerjee, S., Kar, G., Rao, V. U. M., Gadgil, A. S., and Parihar, J. S.: Evapotranspiration using MODIS data and limited ground observations over selected agroecosystems in India, Int. J. Remote Sens., 28(10), 2091-2110, 2007.

Mu, Q., Heinsch, F. A., Zhao, M., and Running, S. W.: Development of a global evapotranspiration algorithm based on MODIS 
and global meteorology data, Remote Sens. Environ., 111, 519536, 2007.

Nagler, P. L., Cleverly, J., Glenn, E., Lampkin, D., Huete, A., and Wan, Z. M.: Predicting riparian evapotranspiration from MODIS vegetation indices and meteorological data, Remote Sens. Environ., 94(1), 17-30, 2005.

Nemani, R. R., White, M. A., Thornton, P., Nishida, K., Reddy, S., Jenkins, J., and Running, S. W.: Recent trends in hydrologic balance have enhanced the carbon sink in the United States, Geophys. Res. Lett., 29(10), 1468, doi:10.1029/2002GL014867, 2002.

Palmer, W.: Meteorological drought, Research Paper 45, US Weather Bureau, Washington DC, 1965.

Patel, N. R., Rakhesh, D., and Mohammed, A. J.: Mapping of regional evapotranspiration in wheat using Terra/MODIS satellite data, Hydrol. Sci. J., 51(2), 325-335, 2006.

Potter, C. S., Randerson, J. T., Field, C. B., Matson, P. A., Vitousek, P. M., Mooney, H. A., and Klooster, S. A.: Terrestrial ecosystem production: a process model based on global satellite and surface data, Global Biogeochem. Cy., 7, 811-841, 1993.

Sánchez, J. M., Scavone, G., Caselles, V., Valor, E., Copertino, V. A., and Telesca, V.: Monitoring daily evapotranspiration at a regional scale from Landsat-TM and ETM+ data: Application to the Basilicata region, J. Hydrol., 351, 58-70, 2008.

Sjöström, M., Ardö, J., Eklundh, L., El-Tahir, B. A., El-Khidir, H. A. M., Hellström, M., Pilesjö, P., and Seaquist, J.: Evaluation of satellite based indices for gross primary production estimates in a sparse savanna in the Sudan, Biogeosciences, 6, 129-138, doi:10.5194/bg-6-129-2009, 2009.
Sun, Z., Wang, Q., Matsushita, B., Fukushima, T., Ouyang Z., and Watanabe, M.: A new method to define the VI-Ts diagram using subpixel vegetation and soil information: a case study over a semiarid agricultural region in the North China Plain, Sensors, 8 , 6260-6279, 2008.

Sun, Z., Wang, Q., Matsushita, B., Fukushima, T., Ouyang, Z., and Waternabe, M.: Development of a simple remote sensing evapotranspiration model (Sim-ReSET): algorithm and model test, J. Hydrol., 376(3-4), 476-485, 2009.

Trigo, I. F., DaCamara, C. C., Viterbo, P., Roujean, J.-L., Olesen, F., Barroso, C., Camacho-de Coca, F., Carrer, D., Freitas, S. C., García-Haro, J., Geiger, B., Gellens-Meulenberghs, F., Ghilain, N., Meliá, J., Pessanha, L., Siljamo, N., and Arboleda, A.: The satellite application facility on land surface analysis, Int. J. Remote Sens., in press, 2011.

Tsakiris, G. and Vangelis, H.: Towards a drought water system based on spatial SPI, Water Resour. Manage., 18(1), 1-12, 2004.

Venturim, V., Islam, S., and RodrigueZ, L.: Estimation of evaporative fraction and evapotranspiration from MODIS products using a complementary based model, Remote Sens. Environ., 112(1), 132-141, 2008.

Wang, K. C., Wang, P., Li, Z. Q., Cribb, M., and Sparrow, M.: A simple method to estimate actual evapotranspiration from a combination of net radiation, vegetation index and temperature, J. Geophys. Res.-Atmos., 112(D15), D15107, doi:10.1029/2006JD008351, 2007. 